\title{
PERNIKAHAN DINI DALAM PERSPEKTIF HUKUM ISLAM
}

\author{
Dwi Rifiani \\ Kementerian Pendidikan \\ dan Kebudayaan Malang \\ rifizenrif@yahoo.com
}

\begin{abstract}
Abstrak
Early marriage is a social phenomenon that commonly happens in all places. This sort of marriage is like iceberg phenomenon which emerges a little bit in the surface, it is rarely exposed, but it is commonly practiced in wider community. If we trace the historical root of early marriage practice in Indonesia, particularly in Javanese island, it has been practiced by the ancestors. In their context, there is a negative stigma for a woman if she marries in the late age among the community. This article will discuss the phenomenon in Islamic law perspective.

Pernikahan dini merupakan fenomena sosial yang banyak terjadi di berbagai wilayah. Fenomena pernikahan dini bagai fenomena gunung es yang hanya tampak sebagian kecil di permukaan, sangat sedikit terekspos di ranah publik, tetapi kenyataannya begitu banyak terjadi di kalangan masyarakat luas. Ketika kita menelusuri akar sejarah tentang pernikahan dini di Indinesia, khususnya di pulau Jawa sebenarnya sudah menjadi sesuatu yang lumrah dilakukan oleh kakek dan nenek moyang kita. Pada konteks mereka, terdapat stigma negative jika seorang perempuan menikah di usia matang dalam komunitas mereka. Tulisan ini akan mendiskusikan fenomena pernikahan dini dalam konteks hukum Islam.
\end{abstract}

Kata kunci: Pernikahan Dini, Hukum Islam, Hak Anak

Diskursus tentang pernikahan dini sebenarnya bukan hal baru untuk diperbincangkan. Masalah ini sudah sering diangkat sebagai topik utama di berbagai diskusi. Sekalipun demikian, masalah ini selalu menarik keinginan para kawula muda untuk menelisik lebih jauh tentang apa dan bagaimana pernikahan dini. Istilah pernikahan dini merupakan istilah yang relatif kontemporer.Dinibiasanya dikaitkandengan waktu, yakni waktu yang sangat awal. Lawannya adalah pernikahan kadaluwarsa. Bagi orang-orang yang hidup pada awal abad 20 atau sebelumnya, pernikahan dini adalah sesuatu yang biasa dilakukan, bukan sesuatu yang dinilai tabu dan tidak penting untuk dimunculkan ke permukaan.
Seiring berkembangnya zaman, image yang berkembang di masyarakat justru sebaliknya. Arus globlalisasi yang melesat sangat cepat banyak merubah paradigm berpikir masyarakat secara luas. Pernikahan di usia yang sangat belia dianggap sebagai sesuatu yang tabu, karena dipandang sebagai banyak membawa efek negatif khususnya bagi pihak perempuan. Sekalipun demikian fenomena pernikahan dini masih banyak dijumpai terutama di daerah-daerah yang mayoritas tingkat kesadaran pendidikannya masih relatif rendah.

\section{Fenomena Pernikahan Dini di Indonesia}

Di Indonesia undang-undang yang me- 
ngatur tentang pernikahan tertuang dalam Undang-Undang No. 1 Tahun 1974 yang menyatakan bahwa pernikahan adalah ikatan lahir batin antara seorang pria dengan seorang wanita sebagai seorang suami istri dengan tujuan membentuk keluarga yang bahagia dan kekal berdasarkan Ketuhanan Yang Maha Esa. Adapun batas usia pernikahan dalam Undang-Undang Perkawinan bab II Pasal 7 ayat 1 disebutkan bahwa pernikahan hanya diijinkan jika pihak pria mencapai umur 19 tahun dan pihak perempuan sudah mencapai umur enam belas tahun. Kebijakan pemerintah dalam menetapkan batasan usia minimal pernikahan ini tentunya sudah melalui proses dan berbagai pertimbangan. Hal ini dimaksudkan agar kedua belah pihak benar-benar siap dan matang dari aspek fisik, psikis, dan mental.

Lebih lanjut dijelaskan dalam Pasal 6 ayat 2 Undang-Undang No. 1 Tahun 1974 bahwa untuk melangsungkan pernikahan seseorang yang belum mencapai usia 21 tahun harus mendapat ijin dari kedua orang tuanya. Namun dalam prakteknya di masyarakat secara umum masih banyak yang melangsungkan pernikahan di usia muda atau di bawah umur. Secara nasional pernikahan dini dengan usia di bawah 16 tahun sebanyak 26,95\%. Bahkan berdasarkan temuan dari Bappenas tahun 2008 menyatakan bahwa 34,5\% dari 2.049.000 perkawinan tahun 2008 adalah pernikahan anak di bawah umur. ${ }^{1}$ Padahal usia pernikahan yang ideal bagi perempuan adalah 21-25 tahun, sedangkan bagi laki-laki adalah 25-28 tahun. Karena pada usia tersebut organ reproduksi pada perempuan sudah berkembang dengan baik dan kuat, serta secara psikologis sudah dianggap matang untuk menjadi calon orang tua bagi anakanaknya. Sementara kondisi fisik dan psikis laki-laki pada usia tersebut juga sudah kuat sehingga mampu menopang kehidupan keluarga dan melindunginya baik secara psikis emosional, ekonomi, dan sosial.

${ }^{1}$ http://www.wikiberita.net/health/168032. Dampak negatif pernikahan dini.html
Pernikahan dini berdampak pada kesehatan reproduksi anak perempuan. Anak perempuan berusia 10-14 tahun memiliki kemungkinan meninggal lima kali lebih besar dibanding perempuan yang berusia antara 20-25 tahun. Sementara anak yang berusia 15-19 tahun kemungkinannya dua kali lebih besar. Prof. Dr. dr. Dadang Hawari, seorang psikiater menyatakan bahwa secara Psikologis dan biologis, seseorang matang berproduksi dan bertanggung jawab sebagai ibu rumah tangga antara usia 20-25 tahun bagi perempuan atau 25 sampai 30 tahun bagi lakilaki. Sebelum usia tersebut dianggap terlalu cepatyang disebutnya dengan istilah pre-cocks yaitu matang sebelum waktunya. ${ }^{2}$ Kondisi yang berkembang memberikan gambaran konkret bahwa pernikahan yang dilakukan tanpa kesiapan dan pertimbangan yang matang dari satu sisi dapat mengindikasikan sikap tidak apresiatif terhadap makna nikah dan bahkan lebih jauh bisa merupakan pelecehan terhadap pernikahan itu sendiri selama ini dianggap sakral oleh agama.

Secara umum, sebagian masyarakat yang melangsungkan pernikahan pada usia muda dipengaruhi oleh beberapa faktor, yaitu: (1) Pernikahan dini terjadi karena keadaan ekonomi keluarga yang berada di bawah garis kemiskinan, sehingga dengan menikahkan salah satu anak perempuannya sekalipun masih sangat belia, akan cukup meringankan beban orang tuanya khususnya dari sisi ekonomi; (2) Orang tua, anak, dan masyarakat dengan tingkat kesadaran pendidikan yang rendah umur; (3) Ada kekhawatiran dikalangan orang tua akan mendapatkan aib karena anak perempuannya sudah berpacaran dengan laki-laki segera menikahkannya; (4) Gencarnya media massa baik cetak maupun elektronik khususnya internet yang belum bisa dikendalikan dalam batas aman untuk dikonsumsi publik yang mengekspos pornografi dan adegan-adegan yang tidak layak dipertontonkan secara umum menye-

\footnotetext{
${ }^{2}$ http://www.wahdah.or.id/wahdah-Wahdah Islamiyah
} 
babkan remaja modern kian banyak yang terjerembab dalam lingkup "permissive society" yang membolehkan pola hidup yang bagaimanapun yang mereka inginkan; (5) Perkawinan usia muda terjadi karena orang tua takut anaknya menjadi perawan tua jika tidak segera menerima pinangan dari lakilaki yang melamarnya. ${ }^{3}$

\section{Pernikahan Dini Melanggar Hak Anak}

Bebarapa waktu yang lalu kita banyak mendengar dan menyaksikan di berbagai media tentang seorang yang sekaligus pengasuh sebuah pesantren, Syekh Puji alias Pujiono Cahyo Widianto usia 43 tahun yang menikahi gadis belia Lutviana Ulfah yang berumur 12 tahun. Berita ini menarik perhatian khalayak karena dianggap peristiwa yang tidak lazim di masa sekarang ini. Peristiwa ini banyak mengundang reaksi keras terutama dari Komnas Perlindungan Anak. ${ }^{4}$ Bahkan banyak pengamat yang berlomba untuk memberikan opini dengan berbagai versi. Padahal pernikahan dini dengan alasan apapun ditinjau dari berbagai aspek sangat merugikan kepentingan anak dan akan sangat membahayakan kesehatan anak. Adapun dampak dari pernikahan dini dapat dinilai dari berbagai pendekatan sudut pandang, yaitu:

\section{Dampak Terhadap Hukum}

Pernikahan dini apabila dilakukan berarti telah mengabaikan beberapa hukum yang telah ditetapkan, antara lain: (a) UndangUndang No. 1 Tahun 1974 tentang Perkawinan "Perkawinan hanya diijinkan jika pihak pria sudah berusia 19 tahun dan pihak wanita sudah berusia 16 tahun" (Pasal 7 ayat 1). "Untuk melangsungkan perkawinan seorang yang belum mencapai umur 21 tahun harus mendapat ijin kedua orang tuanya" (Pasal 6 ayat 2), (b) Undang-Undang No. 23 Tahun 2002 tentang Perlindungan Anak (Pasal 26 ayat 1 ) "Orang tua berkewajiban dan bertanggung ja-

\footnotetext{
${ }^{3}$ http://alfiyah 23.student.umm.ac.id

${ }^{4}$ http://www.pesantrenvirtual.com/index.php? Pernikahan Dini dalam Perspektif Agama dan Negara
}

wab untuk mengasuh, memelihara, mendidik, dan melindungi anak, (c) Undang-Undang No. 21 tahun 2007 tentang Pemberantasan Tindak Pidana Perdagangan Orang.

Amanat undang-undang tersebut bertujuan untuk melindungi anak agar tetap memperoleh haknya untuk hidup, tumbuh, berkembang serta terlindungi dari perbuatan kekerasan, eksploitasi dan diskriminasi ${ }^{5}$.

\section{Dampak Biologis dan Psikologis}

Secara biologis, organ-organ reproduksi anak yang baru menginjak akil baligh masih berada pada proses menuju kematangan sehingga belum siap untuk melakukan hubungan seks dengan lawan jenisnya, apalagi jika sampai hamil dan melahirkan. Jika dipaksakan yang terjadi justru malah sebuah trauma, perobekan yang luas dan infeksi yang akan membahayakan organ reproduksinya sampai membahayakan jiwa anak. Patut dipertanyakan apakah hubungan seks yang demikian atas dasar kesetaraan dalam hak reproduksi antara istri dan suami atau adanya kekerasan seksual dan pemaksaan terhadap seorang anak.

Secara psikis anak belum siap dan belum mengerti tentang hubungan seks, sehingga akan menimbulkan trauma psikis berkepanjangan dalam jiwa anak yang sulit disembuhkan.

\section{Dampak Sosial dan Perilaku Seksual}

Fenomena sosial ini berkaitan dengan faktor sosial budaya dalam masyarakat yang cenderung memposisikan wanita sebagai pelengkap kehidupan laki-laki saja. Kondisi ini hanya akan melestarikan budaya patriarkhi yang kebanyakan hanya akan melahirkan kekerasan dan menyisakan kepedihan bagi perempuan.

Adanya perilaku seksual berupa perilaku gemar berhubungan seksual dengan anak-anak yang dikenal dengan sebutan pedofilia. Perbuatan ini tidak sesuai dengan Undang-Undang No. 23 tahun 2002 tentang

\footnotetext{
${ }^{5}$ http://alfiyah 23. Student.umm.ac.id
} 
Perlindungan Anak khususnya pasal 81 dengan ancaman pidana bagi pelanggarnya berupa hukuman penjara maksimum 15 tahun, minimum 3 tahun dan pidana denda maksimum 300 juta dan minimum 60 juta rupiah. Apabila tidak diambillangkahhukum bagi pelakunya tidak akan menyebabkan efek jera bagi pelaku bahkan akan menjadi panutan bagi yang lain untuk melakukan hal yang sama.

Pihak yang memberikan komentar bahwa pernikahan dini adalah sesuatu yang harus dihindari memberikan alasan karena adanya kekhawatiran bagi banyak kalangan tentang ekses pernikahan dini yang acap kali terjadi dan menggejala di berbagai daerah di tanah air kita khususnya, dan umumnya diberbagai belahan negara di dunia, karena dengan pernikahan dini banyak hak anak yang dilanggar, sebagaimana dipaparkan di atas. Tri Lestari Dewi Saraswati, Direktur Lembaga Studi dan Pengembangan Perempuan dan Anak, Yogyakarta, mengungkapkan ada lima hak anak yang diabaikan dengan adanya pernikahan dini terutama bagi pihak perempuan.

Pertama, hak untuk mendapatkan pendidikan, dengan kasus pernikahan dini, anak tidak melanjutkan sekolah sehingga tidak berkesempatan mengenyam pendidikan yang lebih tinggi, hanya 5,6 persen anak yang menikah di usia dini yang masih melanjutkan sekolah setelah menikah. Kedua, hak untuk berpikir dan berekspresi. Sebagaimana tertuang dalam undang-undang tentang perlindungan anak disebutkan bahwa setiap anak berhak untuk berpikir dan berekspresi sesuai dengan tingkat kecerdasan dan usianya dalam bimbingan orang tuanya. Dalam banyak kasus pernikahan dini anak tidak lagi bisa berpikir dan berekspresi secara bebas sesuai dengan usianya karena dituntut dengan berbagai kewajiban sebagai seorang istri.

Ketiga, hak untuk menyatakan pendapat dan didengar pendapatnya. Perlu dipertanyakan apakah dalam kasus pernikahan dini anak telah diminta pendapatnya dan didengar pendapatnya? Sebab pada kenyataannya orang dewasa cenderung memandang bahwa anak belum mampu menentukan keputusan penting bagi dirinya sendiri. Akhirnya, orang tuanyalah yang menentukan dan mengambil keputusan dengan mengatasnamakan kepentingan yang terbaik bagi anaknya, padahal banyak motif terselubung di balik keputusan itu, salah satu diantara yang banyak terjadi adalah motif ekonomi. Keempat, hak untuk beristirahat dan memanfaatkan waktu luang, bergaul dengan teman sebaya, bermain, dan berkreasi. Kelima, hak perlindungan. Anak seharusnya dilindungi dari pernikahan dini yang berdampak pada perkembangan fisik, mental, dan psikisnya. ${ }^{6}$

Berkaitan dengan adanya sinyalemen bahwa pernikahan dini banyak berdampak pada perkembangan fisik, mental, dan psikis, berikut ini dipaparkan hasil penemuan yang dilakukan oleh Organisasi Pemerhati Anak, Plan Indonesia yang meneliti dampak pernikahan dini di delapan Kabupaten di Indonesia yaitu di Indramayu, Jawa Barat; Grobogan, Rembang, Jawa Tengah; Tabanan, Bali; Dompu, Nusa Tenggara Barat; Timor Tengah Selatan, Sikka, dan Lembata, Nusa Tenggara Timur, dengan hasil yang cukup mencengangkan. Hasil penelitiannya menunjukkan bahwa sebanyak $44 \%$ anak perempuan yang menikah pada usia dini mengalami kekerasan dalam rumah tangga (KDRT) dengan frekwensi tinggi, sementara $56 \%$ dengan frekwensi rendah. Bahkan menurut data yang dilansir Badan Peradilan Mahkamah Agung (MA) Maret 2011, Jawa Timur merupakan daerah dengan kasus KDRT tertinggi di Indonesia. Mahkamah Agung mencatat sedikitnya ada 10.029 kasus perceraian dipicu oleh KDRT, dengan Jawa Timur menempati ranking pertama yaitu sebanyak 4.060 kasus. $^{7}$

Menurut data Bappenas tahun 2008, akibat pernikahan dini terdapat sekitar 690.000

\footnotetext{
${ }^{6}$ Harian Kompas, Pernikahan Dini Langgar Hak Anak, (Jum'at 11 Nopember 2011)

${ }^{7}$ Harian Surya, Sabtu 22 Oktober 2011
} 
kasus perceraian. Kondisi psikologis pasangan yang belum matang menjadi faktor utama penyebab persoalan ini. Menurut perspektif psikologis, pernikahan dini dapat menyebabkan disharmoni keluarga. Disharmoni bisa terjadi karena emosi pasangan yang masih labil dan cara berpikir yang masih setengah matang. Disamping itu, pernikahan dini juga berkorelasi cukup signifikan dengan tingkat kematian ibu hamil atau melahirkan, aborsi, perdagangan manusia, jumlah anak terlantar, dan pengangguran. Bahkan secara psikologis ketika anak melakukan pernikahan dini tidak dapat beradaptasi dengan lingkungan dan situasi barunya maka dapat mengakibatkan timbulnya stress yang berdampak tidak baik bagi dirinya maupun bayi yang dikandungnya.

Bertolak dari beberapa kasus yang dipaparkan di atas, Country Director Plan, John Mc Donough menyatakan keprihatinannya terhadap angka pernikahan dini di Indonesia. Ada beberapa upaya yang bisa dilakukan untuk mencegah terjadinya pernikahan di bawah umur ini yaitu dengan program pemberdayaan anak perempuan meliputi pemberdayaan yang ada hubungannya dengan ekonomi keluarga, advokasi, pendidikan dan penelitian tentang pernikahan dini, serta kampanye pemberdayaan dan partisipasi anak perempuan. Program-program ini akan berhasil secara optimal tentu saja juga harus melibatkan laki-laki dewasa seperti ayah, saudara laki-laki, dan suami. ${ }^{8}$

Selain hal di atas pemerintah juga harus serius dalam menegakkan hukum yang berlaku terkait pernikahan anak di bawah umur sehingga pihak-pihak yang ingin melakukan pernikahan dengan anak yang masih di bawah umur akan berpikir dua kali sebelum melakukannya. Di samping itu pemerintah juga harus semakin giat mensosialisasikan undang-undang terkait pernikahan anak di bawah umur berikut sanksi-sanksi bila melakukan pelanggaran dan menjelaskan risiko-risiko terburuk yang bisa terjadi aki-

${ }^{8} \mathrm{http}: / /$ metrotvnews.com/read/news, Minggu, 25 September 2011 bat pernikahan anak di bawah umur kepada masyarakat. Diharapkan dengan upaya tersebut masyarakat tahu dan sadar bahwa pernikahan dini adalah sesuatu yang salah dan harus dihindari. Sinergi antara pemerintah dan masyarakat merupakan jurus terampuh untuk saat ini agar pernikahan dini dapat terhindarkan sehingga ke depan diharapkan tidak ada lagi anak yang menjadi korban akibat pernikahan dini sehingga calon generasi bangsa bisa lebih optimis menatap masa depannya kelak.

Satu permasalahan yang tidak bisa kita nafikan adalah kenyataan yang saat ini menjadi gaya hidup remaja, yaitu pacaran. Seakanakan sudah menjadi sesuatu yang biasa saja ketika seorang remaja berpacaran dengan lawan jenisnya karena hal itu dianggap oleh sebagian pihak sebagai sebuah kebutuhan dan tahapan yang harus dilalui oleh kaum remaja. Sepertinya, kalau tidak melakukan hal itu dianggap kuno. Kondisi seperti inilah yang melatarbelakangi berkembangnya seks bebas di kalangan kawula muda di berbagai Negara, termasuk para remaja di Indonesia. Data yang diperoleh PBB mengatakan bahwa lebih dari $80 \%$ siswa SMA di Cina pernah melakukan seks bebas. ${ }^{9}$ Bahkan hasil penelitian di kota Malang beberapa tahun yang lalu menunjukkan bahwa lebih dari $50 \%$ mahasiswa di Malang sudah pernah melakukan seks bebas.

Fenomena itu memang sangat memprihatinkan, sekalipun hasil penelitian ini masih perlu dipertanyakan lagi validitas datanya. Dengan demikian jika ada yang mempertanyakan mengapa menikah dipersulit, bergaul bebas dipermudah. Kadangkadang terasa adanya keanomalian dalam kasus ini. Nikah yang jelas ada syariatnya dipersulit dengan keharusan mengurus keadministrasian, selain adanya peraturan pemerintah akan adanya batasan usia untuk seseorang boleh melangsungkan pernikahan. Di sisi lain, sarana untuk bergaul bebas dipermudah mengaksesnya dan disediakan fasilitas yang sangat gampang dijangkau oleh ${ }^{9} \mathrm{http}: / /$ alfiyah 
siapa saja termasuk mereka yang berkantong tipis.

Kenyataan bahwa ada beberapa kendala seperti masalah biaya dan kesiapan mental ketika seseorang ingin melegalkan hubungan yang dirajutnya baik legal menurut agama maupun menurut hukum nasional. Tidaklah mengherankan jika mereka mencari solusi yang bisa ditempuhnya untuk menyalurkan naluri biologis yang sulit dijinakkan tersebut, sehingga mereka melakukan seks bebas. Bahkan yang cukup membuat hati kita bergidik adalah keyakinan mereka bahwa Married By Accident (MBA), suatu istilah bagi sepasang muda mudi yang menikah disebabkan sang perempuan telah diberi 'down payment" terlebih dahulu dianggap sebagai jalan terbaik ketika mereka kebablasan berpacaran. Bukan tidak mungkin seseorang sengaja menghamili pacarnya bila hubungan mereka tak direstui oleh orang tuanya. Mereka beranggapan kalau pacarnya "kecelakaan" (hamil) pasti mereka akhirnya dinikahkan juga.

Dalam kondisi yang sudah sedemikian parah, penulis beranggapan bahwa pernikahan dini layak diberi tempat sebagai salah satu alternatif yang aman, baik secara agama maupun hukum Negara, dari pada dengan membiarkan mereka terperosok ke dalam lembah kenistaan yang lebih kelam. Langkah ini tentu saja tidak boleh mengesampingkan dan harus tetap memperhatikan hal-hal urgen yang akan berakibat fatal apabila tidak mendapatkan perhatian secara baik. Karena dengan menutup sama sekali celah dan kesempatan yang membolehkan pernikahan dini, maka dekadensi moral yang terjadi di kalangan remaja akan semakin merajalela. Bahkan bukan tidak mungkin kita juga akan ikut berdosa jika hal semacam ini kita abaikan tanpa merasa ikut bertanggung jawab bagaimana memperbaiki kondisi yang sudah carut marut ini.

\section{Pernikahan Dini dalam Perspektif Hukum Islam}

Substansi hukum Islam adalah mencipta- kan kemaslahatan sosial bagi manusia baik di masa sekarang maupun di masa yang akan datang. Hukum Islam bersifat luas dan luwes, humanis, dan selalu membawa rahmat bagi seluruh manusia di alam ini. ${ }^{10}$ Termasuk dalam ranah pemikiran tentang hal ini adalah ayat-ayat dan hadis-hadis Nabi yang mengupas masalah pernikahan, karena pada prinsipnya semua perbuatan orang muslim yang sudah akil baligh tidak bisa terlepas dari hukum syara' sebagaimana terumuskan dalam kaidah syara' al ashlu fi al 'af'aal at-taqayyudu bi al-hukmi al-syar'iyy. ${ }^{11}$ Pada mulanya hukum menikah adalah sunnah sesuai dengan Al-Qur'an Surat An-Nisa' ayat 3:

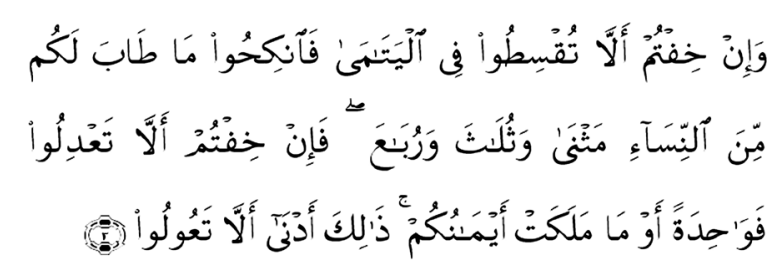

"Dan jika kamu takut tidak akan dapat Berlaku adil terhadap (hak-hak) perempuan yang yatim (bilamana kamu mengawininya), Maka kawinilah wanita-wanita (lain) yang kamu senangi: dua, tiga atau empat. kemudian jika kamu takut tidak akan dapat Berlaku adil, Maka (kawinilah) seorang saja, atau budak-budak yang kamu miliki. yang demikian itu adalah lebih dekat kepada tidak berbuat aniaya."

Perintah untuk menikah pada ayat di atas merupakan tuntutan untuk melakukan pernikahan (thalabul fi'li), namun tuntutan tersebut bersifat sunnah, bukan sebuah keharusan karena adanya kebolehan memilih antara kawin dan pemilikan budak. Namun hukum asal sunnah ini dapat berubah menjadi wajib, haram, maupun makruh, jika seseorang tidak bisa menjaga kesucian diri dan akhlaknya kecuali dengan menikah, maka menikah menjadi wajib baginya. Sebab menjaga kesucian dan akhlak hukumnya wajib bagi setiap muslim. Adapun menikah dini, yaitu menikah pada usia remaja atau muda, bukan usia tua, hukumnya sunnah

${ }^{10}$ Imam Syathibi, Al-Muwafaqat, (Beirut, Libanon: Darul Kutub Ilmiah) h. 220

${ }^{11}$ Taqiyuddin An-Nabhani, Asy-Syakhsiyyah alIslamiyah Juz III, 1953. h. 19 
atau mandub, demikian menurut Imam Taqiyuddin An-Nabhani dengan berlandaskan pada hadis Nabi yang artinya: "Wahai para pemuda, barang siapa yang telah mampu, hendaklah menikah, sebab dengan menikah itu akan lebih menundukkan pandangan dan akan lebih menjaga kehormatan. Kalau belum mampu, hendaklah berpuasa, sebab puasa akan menjadi perisai bagimu" (HR. Bukhari dan Muslim).

Satu hal yang perlu digaris bawahi dari hadits di atas adalah perintah menikah bagi para pemuda dengan syarat jika ia telah mampu, maksudnya adalah siap untuk menikah. Kesiapan menikah dalam tinjauan hukum Islam meliputi 3 hal, yaitu: (a) Kesiapan ilmu, yaitu kesiapan pemahaman hukumhukum fikih yang ada hubungannya dengan masalah pernikahan, baik hukum sebelum menikah, seperti khitbah (melamar), pada saat menikah seperti syarat dan rukun akad nikah, maupun sesudah menikah seperti hukum menafkahi keluarga, thalak, rujuk. Syarat pertama ini didasarkan pada prinsip bahwa fardu 'ain hukumnya bagi seorang muslim untuk mengetahui hukum perbuatan seharihari yang dilakukannya atau yang akan dilakukannya; (b) Kesiapan harta atau materi, yang dimaksud dengan harta di sini ada dua macam yaitu harta sebagai mahar dan harta sebagai nafkah suami kepada istrinya untuk memenuhi kebutuhan pokok (al-hajat alasasiyyah) bagi istri berupa sandang, pangan, dan papan yang wajib diberikan dalam kadar yang layak (bil ma'ruf); (c) Kesiapan fisik atau kesehatan khususnya bagi laki-laki, yaitu mampu menjalani tugasnya sebagai suami, tidak impoten. Khalifah Umar bin Khaththab pernah memberi penangguhan selama satu tahun kepada seorang laki-laki (suami) yang impoten untuk berobat. Ini menunjukkan bahwa kesiapan "fisik" yang satu ini perlu mendapat perhatian serius.

Sekalipun dikatakan bahwa pernikahan dini hukum asalnya diperbolehkan menurut syariat Islam, tetapi tidak berarti ia dibolehkan secara mutlak bagi semua perempuan dalam semua keadaan. Sebab pada sebagian perempuan terdapat beberapa kondisi yang menunjukkan bahwa lebih baik ia tidak menikah pada usia dini. terdapat beberapa ketentuan yang perlu diperhatikan dalam sebuah pernikahan dini agar tidak mengakibatkan efek negatif sebagaimana dilansir oleh banyak kalangan yang mayoritas berpandangan bahwa pernikahan dini selalu berkonotasi tidak baik.

Pertama, perempuan harus sudah siap secara fisik, karena banyak perempuan yang sudah baligh namun belum siap untuk menikah karena kondisi tubuhnya yang lemah atau penyakit yang membuatnya tidak memiliki fisik yang prima sehingga tidakmampu menjalankan tugasnya sebagai istri. Kedua, perempuan tersebut sudah matang secara mental dan terdidik untuk dapat memenuhi tanggung jawab. Ini bukan berarti ia harus mengetahui seluk beluk kehidupan berumah tangga secara sempurna ketika berinteraksi dengan suami, mengasuh anak, dan lain sebagainya. Kedua poin tersebut pantas mendapat perhatian lebih berdasar hadis Nabi bahwa beliau tidak menyuruh menikah kepada seluruh pemuda tanpa terkecuali bagi mereka yang dianggap mempunyai al-bâ'ah, yaitu kemampuan memberi nafkah.

Ketiga, pada pernikahan perempuan yang masih sangat belia, lebih utama kalau dia dan calon suaminya tidak terpaut jauh usianya, kecuali untuk maksud yang dibenarkan. Imam An-Nasa'i telah mengeluarkan sebuah riwayat di dalam Sunan-nya, demikian pula Ibnu Hibban di dalam Shahihnya, serta AlHakim di dalam Al-Mustadraknya, dan ia menilai shahih riwayat tersebut berdasarkan syarat Bukhari dan Muslim yang disepakati olehAdz-DzahabidariBuraidah, menyatakan bahwa Abu Bakar dan Umar melamar Fathimah, namun Rasulullah saw kemudian menikahkan Fathimah dengan Ali. Dari hadis tersebut dapat diambil kesimpulan bahwa usia calon suami perlu diperhatikan, yaitu sebaiknya tidak jauh dengan usia perempuan. Karena kedekatan jarak usia ini diharapkan akan lebih dapat melahirkan keserasian diantara pasangan suami istri, dan lebih dapat melanggengkan pernikahan 
mereka.

Terkait pernikahan Rasulullah saw dengan Aisyah ra, ada beberapa hadis yang menunjukkan bahwa pernikahan tersebut mendasarkan pada sebuah mimpi, dan mimpi para Rasul adalah benar. Jadi hal itu merupakan ketentuan Allah yang diberlakukan untuk Nabi Muhammad saw yang tidak serta merta harus diikuti sebagai sunnah Rasul, sama seperti Rasul yang beristri lebih dari 4 wanita yang juga tidak boleh langsung diterapkan oleh umatnya dengan dalih melaksanakan sunahnya. Ini merupakan salah satu kekhususan bagi Nabi yang tidak berlaku untuk umatnya pada umumnya.

Pernikahan Nabi Muhammad denga Aisyah berdasarkan mimpi ini diungkapkan dalam sebuah hadis dari Aisyah yang diriwayatkan oleh Imam muslim bahwasanya Rasulullah saw bersabda: "Engkau diperlihatkan kepadaku di dalam mimpi selama tiga hari. Seorang malaikat datang membawamu di dalam sepotong kain sutera. Malaikat itu berkata: "Ini adalah istrimu". Aku lalu menyingkap wajahmu, ternyata wanita itu adalah engkau. Akupun berkata; "Kalau ini berasal dari Allah, maka Dia akan mewujudkannya." Perkawinan yang penuh berkah itupun membawa kebaikan yang besar, karena Aisyah atas kehendakNya menjadi salah satu dari Ummahatul Mukminin yang mampu menguasai ribuan hadis dan menjadi "the life reference."

Begitu banyak pelajaran yang bisa kita eksplorasi dari hikmah disyariatkannya suatu hukum baik itu mubah, sunnah, wajib, makruh, maupun haram. Jika kita cermati lebih detail bahwa ternyata pernikahan dini berdampak positif bagi kemaslahatan jika dilakukan dengan tanpa adanya unsur keterpaksaan baik karena kemauan orang tua maupun terpaksa menikah karena sudah telanjur hamil. Beberapa efek positif yang ditimbulkan dari pernikahan dini adalah: Pertama, meminimalisir terjadinya perbuatan asusila dan perilaku menyimpang di kalangan muda-mudi; Kedua, apabila jarak usia orang tua dan anak berdekatan, maka ketika anaknya membutuhkan perhatian dalam hal biaya pendidikan, diharapkan orang tuanya masih sehat wal afiyat untuk menunaikan kewajiban tersebut. ${ }^{12}$ Ketiga, saat belum menikah, anak-anak muda senantiasa dihinggapi lintasan-lintasan pikiran yang mengganggu. Pelampiasan nafsu akan menjadi tujuan yang paling penting, terutama saat mereka asyik berpacaran dengan lawan jenisnya. Karena itu untuk menghindari dampak negative, maka keputusan untuk melakukan pernikahan dini dapat dibenarkan;

Keempat, memiliki tingkat kemungkinan hamil yang tinggi. Kehamilan bagi perempuan yang menikah pada usia muda akan lebih tinggi kemungkinannya dibandingkan dengan pernikahan yang dilakukan di usia yang "sangat matang." Kelima, meningkatkan jumlah populasi umat Islam. Karena rentang masa produktifnya yang sedemikian panjang memungkinkan menghasilkan keturunan yang jauh lebih banyak. Diharapkan bukan hanya jumlah populasi secara kuantitas yang semakin banyak tetapi populasicalon penerus genarasi yang banyak secara kuantitas dan tinggi secara kualitas; Keenam, meringankan beban para orang tua yang terlalu fakir, dan menyalurkan hasrat sang suami secara syar' $i$; Ketujuh, kemandirian sepasang suami istri untuk memikul tanggung jawabnya sendiri tanpa menjadi tanggungan orang lain.

Selain dampak positif pernikahan dini yang diuraikan di atas berikut ini, akan dipaparkan pula efek negatif menunda-nunda pernikahan, diantaranya: (a) Wanita hamil beresiko tinggi bagi mereka yang kehamilan pertama dialami pada usia tertentu yang terus menunda pernikahan sehingga akan membahayakan baik bagi ibu hamil maupun bagi bayi yang dikandungnya; (b) Mengakibatkan keengganan atau lemahnya semangat para pemuda untuk menikah

${ }^{12}$ Dr. Alexis Carell, "Man, The Unknown", mengatakan bahwa semakin dekat jarak waktu nyang memisahkan antara dua generasi, semakin kuat pula pengaruh moral orang tua kepada anaknya, h. 215 
sehingga fenomena hidup melajang menjadi salah satu pilihan atau gaya hidup karena sudah merasa mampu memenuhi kebutuhannya sendiri tanpa perlu ada orang yang mendampingi hidupnya sebagai pasangan hidup; (c) Semakin mundur usia nikah akan semakin menurun semangat orang untuk menikah dan ini banyak terjadi di Negara-negara Barat, sehingga banyak perempuan yang melahirkan anak tanpa proses pernikahan. Mereka lebih memilih hamil dengan cara inseminasi buatan dengan sel sperma yang mereka bisa dapatkan di Bankbank sperma; (d) Kanker payudara dan rahim lebih kecil prosentasenya bagi wanita yang pernah hamil di usia muda dari pada mereka yang hamil pada usia yang sangat matang; (e) Kehamilan di luar rahim bagi wanita berusia sangat matang kemungkinannya lebih besar daripada pada wanita yang berusia antara 15-24 tahun; (f) Ilmuwan Amerika mengatakan bahwa perbandingan jumlah kasus aborsi pada wanita di atas usia 35 tahun lebih banyak 3 sampai 4 kali dibandingkan dengan wanita yang hamil di bawah usia tersebut; (g) Operasi caesar, kelahiran prematur, cacat fisik, kematian janin di dalam rahim sebelum lahir, akan lebih besar kemungkinannya ketika usia ibu hamil semakin banyak bertambah. ${ }^{13}$

\section{Kesimpulan}

Memang wajar jika ada kekhawatiran pihak-pihak tertentu bahwa pernikahan di usia dini akan menghambat studi atau rentan konflik yang berujung pada perceraian, akibat kekurangsiapan mental dari kedua pasangan yang belum dewasa. Namun sebetulnya kekhawatiran dan kecemasan tim-

\footnotetext{
${ }^{13}$ Al-fadlil Abu Ammar Ali Al-Hudzaifi, "Hikmah dan Ketentuan Pernikahan Dini," dalam Jurnal Salafiyyun http:// fadhlihsan.wordpress.com
}

\section{DAFTAR PUSTAKA}

Abu Ammar Ali Al-Hudzaifi, Al-fadlil, Hikmah dan Ketentuan Pernikahan Dini,dalam Jurnal Salafiyyun http:// fadhlihsan.wordpress.com bulnya persoalan-persoalan psikis dan sosial telah dijelaskan dengan gamblang oleh Mohammad Fauzil Adzim dalam bukunya "Indahnya Pernikahan Dini", demikian juga dalam buku "Children Development Through" yang ditulis oleh Clarke-Stewart \& Koch, bahwa pernikahan di usia remaja dan masih duduk di bangku sekolah bukan penghalang untuk meraih prestasi yang lebih baik, bahwa usia bukan ukuran utama untuk menentukan kesiapan mental dan kedewasaan seseorang untuk meraih puncak prestasi yang lebih cemerlang.

Disamping itu, salah satu faktor dominan yang sering membuat keraguan dalam melangkah adalah kesiapan dari sisi ekonomi. Ini memang wajar, tapi bukankah Allah telah menjanjikan bagi hambanya dengan limpahan karunia-Nya. Tuhan pasti menjamin rejeki hambanya yang menikah sebagaimana tersirat dalam Al-Qur'an Surat An-Nur ayat 32 :

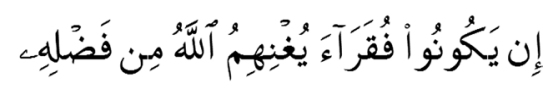

"Jika mereka miskin Allah akan memampukan mereka dengan Karunia-Nya".

Dengan mengikuti pada hukum asalnya, maka pernikahan dini hukumnya boleh untuk kemaslahatan. Karenanya tidak ada alasan untuk menunda-nunda pernikahan selama kita yakin melangkah dengan iringan niat yang tulus melaksanakan syariat Islam. Pernikahan dinitidak akan menjadi perintang seseorang untuk berkreasi, melanjutkan studi, bersosialisasi, bahkan meniti karir yang lebih tinggi. Selama segala persyaratan di atas dipenuhi, pernikahan dini bukan menjadi batu terjal yang menghalangi kita dalam meniti studi menata asa, merenda kasih sayang, menuai bahagia. Wallahu a'lam bi al-shawab.

http://www.wahdah.or.id/wahdah-Wahdah Islamiyah

http://alfiyah 23.student.umm.ac.id

http://www.pesantrenvirtual.com/index. 
134 I de Jure, Jurnal Syariah dan Hukum, Volume 3 Nomor 2, Desember 2011, hlm. 125-134

php? Pernikahan Dini dalam Perspektif Agama dan Negara

http://alfiyah 23. Student.umm.ac.id

Harian Kompas. Jum'at 11 Nopember 2011.

Pernikahan Dini Langgar Hak Anak

Harian Surya. Sabtu 22 Oktober 2011 http://metrotvnews.com/read/news, Minggu, 25 September 2011

http://alfiyah Imam Syathibi, Al-Muwafaqat. T. th. Beirut, Libanon: Darul Kutub Ilmiah

Taqiyuddin An-Nabhani. 1953. AsySyakhsiyyah al-Islamiyah Juz III 